\title{
Horse bone marrow mesenchymal stem cells express embryo stem cell markers and show the ability for tenogenic differentiation by in vitro exposure to BMP-I 2
}

\author{
Stefania Violini*, Paola Ramelli, Laura F Pisani, Chiara Gorni and \\ Paola Mariani
}

Address: Livestock Genomics Unit, Parco Tecnologico Padano, CERSA, Via Einstein, Loc Cascina Codazza, 26900, Lodi, Italy

Email: Stefania Violini* - stefania.violini@tecnoparco.org; Paola Ramelli - paola.ramelli@tecnoparco.org;

Laura F Pisani - laura.pisani@tecnoparco.org; Chiara Gorni - chiara.gorni@tecnoparco.org; Paola Mariani - paola.mariani@tecnoparco.org

* Corresponding author

Published: 22 April 2009

BMC Cell Biology 2009, 10:29 doi:10.1186/147I-2121-10-29

This article is available from: http://www.biomedcentral.com/I47I-2I $21 / 10 / 29$

(C) 2009 Violini et al; licensee BioMed Central Ltd.

This is an Open Access article distributed under the terms of the Creative Commons Attribution License (http://creativecommons.org/licenses/by/2.0), which permits unrestricted use, distribution, and reproduction in any medium, provided the original work is properly cited.
Received: 6 August 2008

Accepted: 22 April 2009

\begin{abstract}
Background: Mesenchymal stem cells (MSCs) have been recently investigated for their potential use in regenerative medicine. MSCs, in particular, have great potential, as in various reports they have shown pluripotency for differentiating into many different cell types. However, the ability of MSCs to differentiate into tendon cells in vitro has not been fully investigated.

Results: In this study, we show that equine bone marrow mesenchymal stem cells (BM-MSCs), defined by their expression of markers such as Oct4, Sox-2 and Nanog, have the capability to differentiate in tenocytes. These differentiated cells express tendon-related markers including tenomodulin and decorin. Moreover we show that the same BM-MSCs can differentiate in osteocytes, as confirmed by alkaline phosphatase and von Kossa staining.

Conclusion: As MSCs represent an attractive tool for tendon tissue repair strategies, our data suggest that bone marrow should be considered the preferred MSC source for therapeutic approaches.
\end{abstract}

\section{Background}

Over the past few years in veterinary medicine there has been an increased interest in understanding the biology of mesenchymal stem cells (MSCs). This interest comes from their potential clinical use especially in wound repair, tissue engineering and application in therapeutics fields, including regenerative surgery $[1,2]$. MSCs can be isolated directly from bone marrow aspirates [3], adipose tissue [4], umbilical cord [5] and various foetal tissues [6]. In the appropriate cell culture conditions they have the capacity to differentiate into several tissues [7], including bone [8], cartilage [9], muscle [10], adipose tissue and produce growth factors and cytokines promoting cell expansion and differentiation [11]. MSCs are an interesting model cell type to study differentiation mechanisms due to the relative ease of establishing in vitro cultures and their good proliferation [12]. Decades of experience have shown that tendons and ligaments regenerate and repair slowly and inefficiently in vivo after injury. Strain induced tendon injuries are a common consequence of athletic endeavour, in both horses and humans, often compromising a return to the previous level of activity. There are many similarities between the weight bearing tendons of the horse and human tendons, eg in matrix composition, and also in the 
nature of the injuries sustained. As tenocytes are highly differentiated cells, they have a limited potential for replication. Moreover, tenocytes are embedded in an extensive three-dimensional network of extracellular matrix components consisting mostly of type I, type III and type V proteoglycans, elastin and fibronectin [13-15].

The development of tendon tissue engineering for wound repair will depend on the identification and characterisation of appropriate sources of cells, as well as the development of new inert scaffolds for tissue regeneration [16]. The identification of an optimal cell source for tendon tissue engineering applications will require a rigorous characterisation of available sources for stem cells with regard to plasticity, propagation and control of differentiation. Under normal physiological conditions fully developed tendon is a poorly vascularised tissue with a low density of cells which exhibit low mitotic activities [17]. This could explain why tendon healing is slow and in most cases results in a mechanically inferior extracellular matrix [18]. Tissue engineering approaches have been investigated to improve tendon rupture healing by transplantation of in vitro cultured tenocytes, obtained from tendons, seeded in matrices [19-21]. These cells are highly specialised mesenchyme-derived cells, responsible for the synthesis and maintenance of a mechanically unique connective tissue, able to resist high tensile forces [22]. Nevertheless, a critical drawback of cellular transplantation approaches using in vitro cultured tenocytes is the loss of differentiated function that occurs during prolonged monolayer culture [23]. MSCs, under appropriate stimulation, represent an opportunity to produce in vitro cells of the required type. Bone morphogenetic proteins (BMPs) have been shown to induce differentiation of mesenchymal stem cells into osteogenic lineage [24]. The bone morphogenetic protein (BMP) family represents a subgroup of molecules within the transforming growth factor $\beta$ (TGF- $\beta$ ) super family. BMPs were identified by their ability to promote ectopic cartilage and bone formation [25]. Among the BMPs isolated so far, BMP-2 and BMP-7 have been used to study tendon-bone healing in animal models [26]. Most importantly, it has been shown that gene transfer of BMP-12, a human homologue growth differentiation factor 7 (GDF7), is required to induce tenocyte differentiation process in MSCs [27]. Therefore, using BMP-12 to induce the development of MSCs into a sufficient number of tenocytes for the repair of a tendon defect was suggested [28]. Therefore adult stem cells, under specific stimulation represent a promising method to obtain in vitro tenocytes for tendon healing.

In this study we describe the in vitro growth of equine bone marrow MSCs. Cells were characterized using recognized molecular markers for "stemness" namely: Nanog, Oct4, Sox-2 and CD34. The undifferentiated cells were morphologically characterized and the presence of PCR products for the "stemness" markers assessed. The expression level of the latter was detected by QRT-PCR. Equine MSCs were induced to differentiate either into osteoblasts or into tenocytes by in vitro exposure to BMP-12. The results are relevant to future tissue engineering applications of this approach to human and equine MSCs in clinical practice.

\section{Results \\ Cell morphology, growth characteristics and Oct4 expression by immunocytochemistry}

By day three after washing and removing the medium containing non-adherent cells, equine BM-MSCs appeared as isolated colonies of adherent elongated cells. Following further passages the equine BM-MSCs cells proliferated uniformly maintaining an homogeneous fibroblast-like morphology with a spindle shaped appearance and growing outward in a "swirling fibroblast-like" pattern. Nuclei were large and elliptical with the presence of a few nucleoli (data not shown). Between $3^{\text {rd }}$ and $10^{\text {th }}$ passage the BM-MSCs had a doubling time of 1,8 days. Immunocytochemical staining showed the expression of Oct4 in most of BM-derived stem cells (Fig. 1).

\section{Marker expression of BM-MS cells}

The presence of Sox-2, Oct4 and Nanog amplicons in BMMSCs was assessed: the expression of these genes is required for self-renewal and demonstrates multilineage differentiation potential $[29,30]$. The cells did not express the surface marker CD34, which is expressed in haematopoietic but not in MSCs (Fig. 2).

The relative expression level of Sox-2, Oct4 and Nanog was assessed by QRT-PCR. Data showed these "stemness" markers to be expressed at comparable level with the constitutive expression of the housekeeping GAPDH gene (Fig. 3).

\section{Tenogenesis of BM-MSCs}

After tenogenesis induction cells were investigated for the expression of tenocytes markers and found to express tenomodulin, which is a tendon-specific gene $[31,32]$ and decorin [33]. To rule out the possible unwanted differentiation into reproduction tissues, the expression of P19 lipocalin was checked (Fig. 4). Differentiated cells did not show P19 expression. This gene is not expressed in tenocytes and is expressed by horse uterine and endometrial tissues [34]. Compared to the untreated BM-MSCs, the differentiated cells showed a significant difference in morphology some being fibroblast-like and others having a more elongated tenocyte-like phenotype (Fig. 5). 


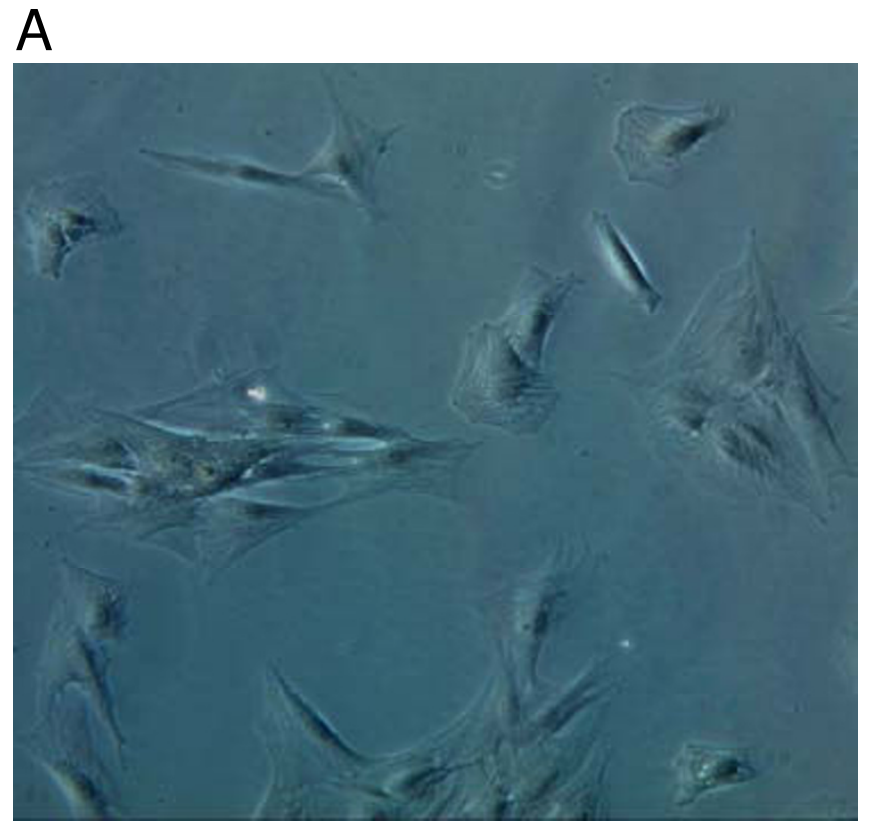

B

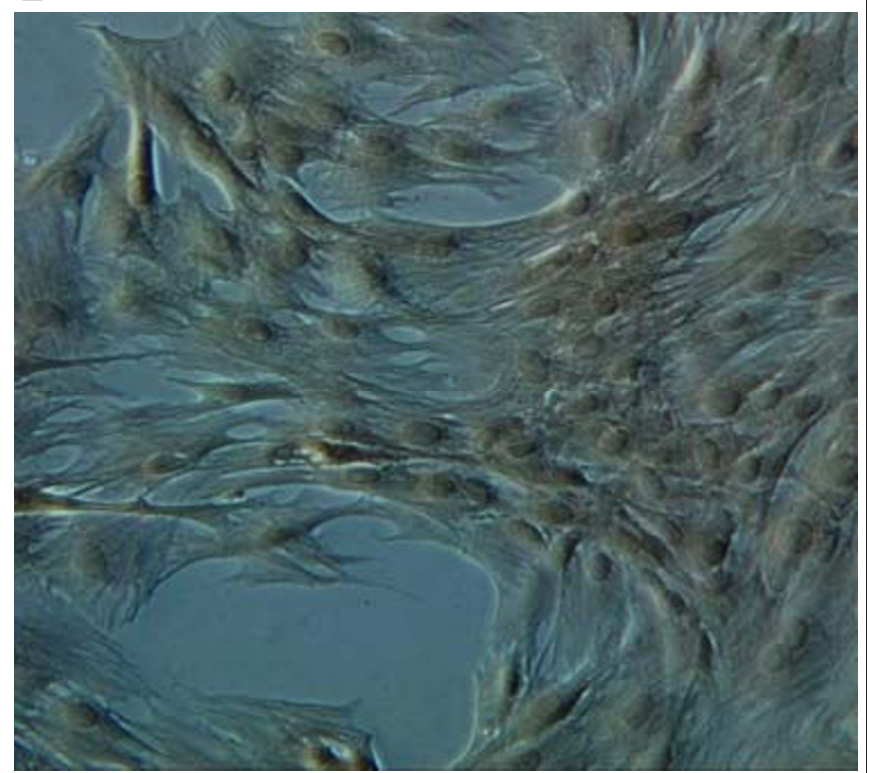

Figure I

BM-derived MSCs express stem cell marker protein Oct4. Cells (5th passage) were fixed and incubated with antibodies directed against Oct4. Immunoreactivity was detected with avidin, biotinylated horseradish peroxydase and 3,3'-Diaminobenzidine (DAB) (IB). IA: negative control, incubated only with secondary antibody. Magnification 20x.

\section{Osteogenic potential of BM-MSCs}

Osteogenic differentiation was induced in the BM-MSCs by a medium containing $\beta$-glycerol phosphate, ascorbic acid and dexamethasone. The BM-MSCs formed calcium deposits identified by von Kossa staining (Fig. 6), suggest-

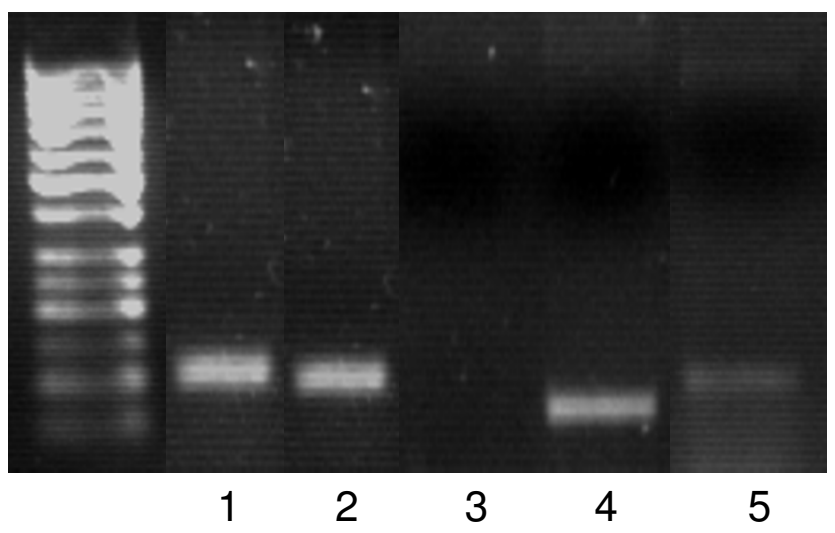

Figure 2

Gene expression analysis of BM-MSCs. The products from RT-PCR analysis of GAPDH (lane I), Oct4 (lane 2), CD34 (lane 3), SOX-2 (lane 4) and Nanog (lane 5) mRNA expression at day 14 (passage 5) in BM-MSCs, showing the expression of mesenchymal stem cell-related markers and lack of expression of CD34. ing the osteogenic potential of our MSCs culture. Moreover, cells stained positively for alkaline phosphatase, which is an indicator of osteogenic differentiation. Following osteogenic induction, the cells changed their morphology and showed more cubical and star-shaped morphology with spikely extensions and increased in size. Neither positive staining for alkaline phosphatase or mineralized matrix was observed in the cells cultured in regular growth medium.

\section{Discussion}

Bone marrow mesenchymal stem cells (BM-MSCs) have been recently investigated as important source of undifferentiated cells in the field of regenerative medicine. As they can potentially differentiate into chondrocytes, adipocytes, osteocytes, myocardial and neural cells, they have become promising candidates as starting cells in tissue engineering studies aimed at improving wound healing and tendon tissue repair $[35,36]$. The technique of equine MSC isolation from bone marrow, ex vivo culture and expansion, has been previously reported [37]. Recently, Vidal described adipose-derive stem cell (ADSC) characteristics compared to BM-derived stem cells [38], mentioning their clinical relevance for tissue engineering applications in equine veterinary medicine, making adipose tissue a possible alternative source to BM. 


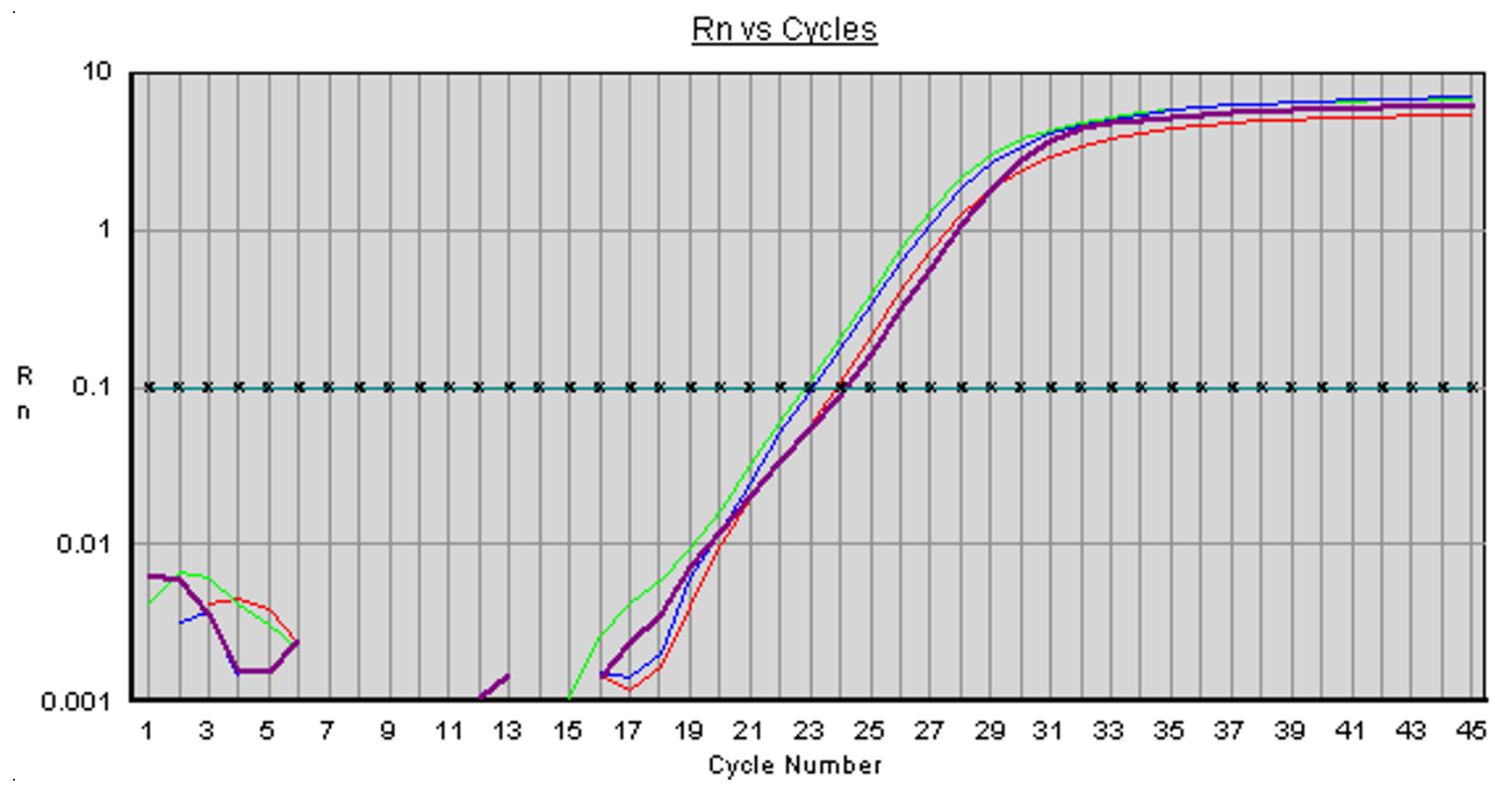

Figure 3

QRT-PCR of BM-MSCs for the Nanog, Oct4, Sox2 and GAPDH genes. Plot of QRT-PCR of Nanog (violet), Oct4 (green), Sox2 (blue) and GAPDH (red) on cDNA from BM-MSC cells. Cycle number is shown on the $\mathrm{X}$-axis and emission intensity of a fluorescent reporter $(\mathrm{Rn})$ is shown on the $\mathrm{Y}$-axis. Fixed threshold is indicated as horizontal line.

Though ADSCs have been reported to display similar characteristics to BM-MSCs in humans in terms of gene expression profiles and phenotypes $[39,40]$, their potential for both chondrogenic differentiation in 3D culture and proteoglycan synthesis and thus their quality in tissue engineering is controversial $[40,41]$. Winter and co-workers [40] found $90 \%$ reduced chondrogenic potential of ADSCs in micromass cultures compared to BM-MSCs and these observations were confirmed by Sakaguchi and coworkers [42], who analyzed various stem cell sources in chondrogenesis studies. Scientific literature has already shown that the methods to isolate BM-MSCs are faster than ADSCs and the yield in terms of purity is higher as in the latter case cells might be contaminated by mixed population of fibroblasts and adipocytes [43]. Moreover, Richardson and co-workers [43] reported MSCs isolation from fat is riskier than from bone marrow as there is more donor-site morbidity because of the surgery.

In general, tendon lesions in horses have been treated with BM-MSCs [35]. These cells have been largely used since they have been shown to be successful in repairing more specifically tendons and ligaments [36].
Adipose stem cell plasticity seems to be limited though compared to $\mathrm{BM}$, as differentiation capabilities in tendonlike cells is still to be proven [44].

The focus of this study was to evaluate growth and differentiation of equine BM-MSCs. Adherent cells from bone marrow were found to actively proliferate in vitro and to maintain their morphological and growth characteristics for over 10 passages. Moreover, our results show that adherent equine BM-MSCs could proliferate rapidly in DMEM with FBS and EGF added with a doubling time of 1.8 day. This finding is comparable to previous studies that found an average cells doubling time of 1.4 days, with no significant difference in the doubling rate between foals and young horses BM-MSCs [38]. In our study cells grown in standard media showed an elongated fibroblastlike morphology, large cell size and capabilities of continuously dividing as has been observed in bone marrow stroma and tissue-specific MSC cells from other species $[45,46]$. RT-PCR analysis showed that Oct4, Nanog and Sox-2 genes were expressed by the stem cells. The following QRT-PCR showed these "stemness" markers were expressed at comparable level with the constitutive gene GAPDH. This data confirms that MSCs from bone marrow of adult animals also expresses embryonic stem cell markers. 


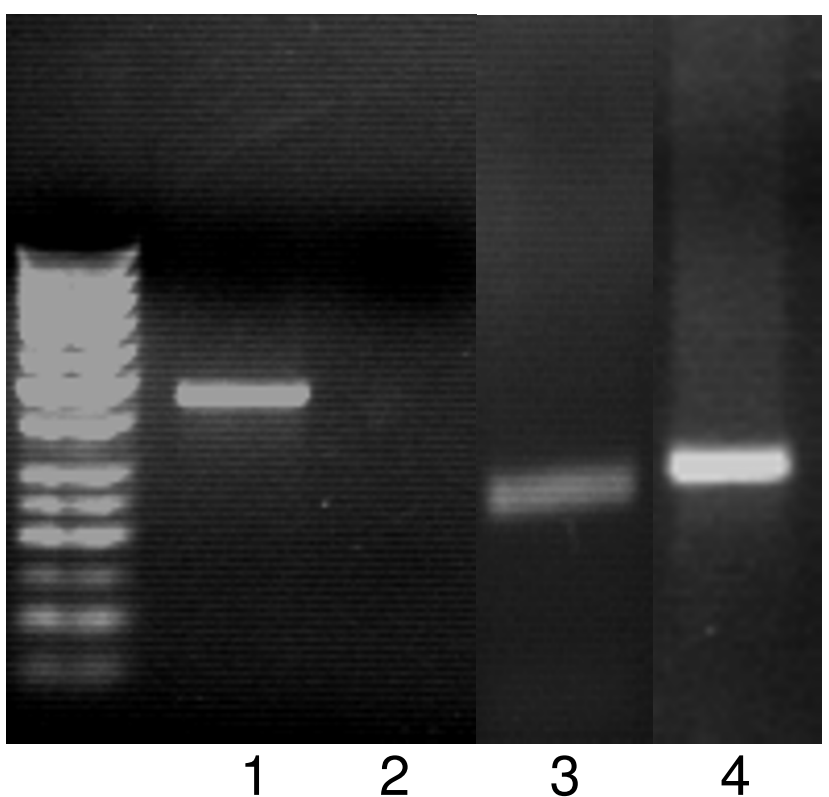

\section{Figure 4}

Gene expression analysis of BM-MSC derived tenocytes. Products from RT-PCR analysis of tenomodulin (lane I), PI 9 lipocalin (lane 3), GAPDH (lane 3) and decorin (lane 4) mRNA expression following 14 days stimulation of BMMSC cells with BMP-12, resulting in differentiation into tenocytes.
Immunocytochemistry experiments confirmed that BMMSCs expressed the embryo stem cell marker Oct4. These cells did not express the haematopoietic lineage marker CD34, thus confirming their characterisation as mesenchymal stem cells [46]. Interestingly, so far only embryonic stem cells had been found to express Oct 4 and Nanog [47]. Recently, two papers reported the expression of Oct4 in equine umbilical cord cells $[44,48]$. In our study we show that also bone marrow-derived mesenchymal stem cells do express both Oct 4 and Nanog. Literature data have considered embryo and adult stem cell markers as part of two different groups of markers. Our discovery that horse bone marrow MSCs express Oct4 and Nanog, together with a documented expression of SSEA-1 in murine MSCs by Anjos-Afonso [49], might indicate that the distinction between embryo and adult markers is not so strict. Having assessed in the present study that embryo stem cell markers are also expressed by adult stem cells, further investigations in the field are needed to identify which still unknown markers are unique and peculiar for embryo stem cells and to characterize embryological patterns in terms of differentiation capabilities. It should be noted that in our study the expression of equine cell markers was assessed by a PCR based panel of specifically designed oligonucleotide primers, instead of using antigen/antibodies based flow cytometry. This panel was used not only to assess the stemness of bone marrow-derived cells, but also to investigate their differentiation in tenocytes. This DNA marker-based panel represents a powerful tool in equine stem cells research, as many positive stem-
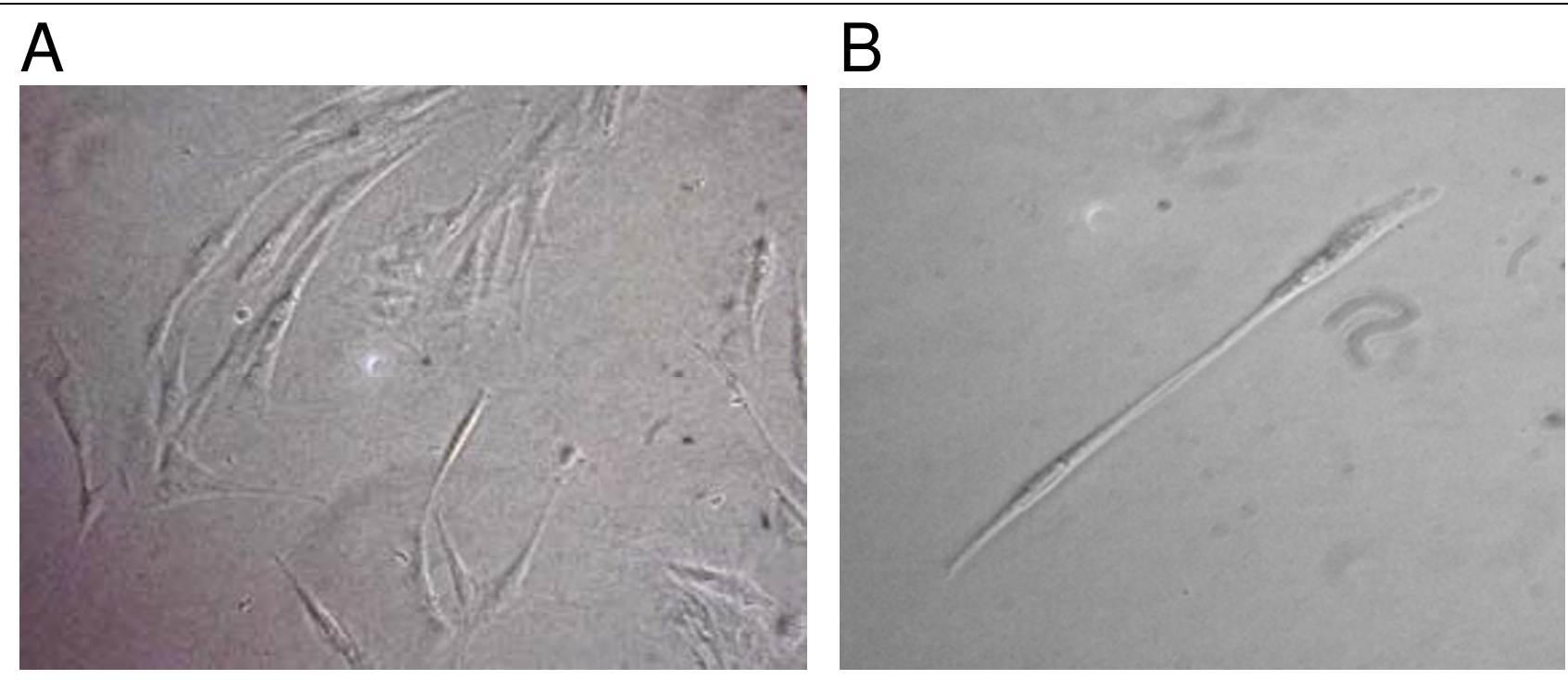

\section{Figure 5}

Morphology of equine BM-MSC-derived tenocytes cultured in monolayer at day $20^{\text {th }}$. The cells at $5^{\text {th }}$ passage in growth medium added with BMP-I 2 under phase contrast microscopy exhibited heterogeneous morphology with most cells fibroblast-like (A) and other elongated cells (B). Magnification I0x. 

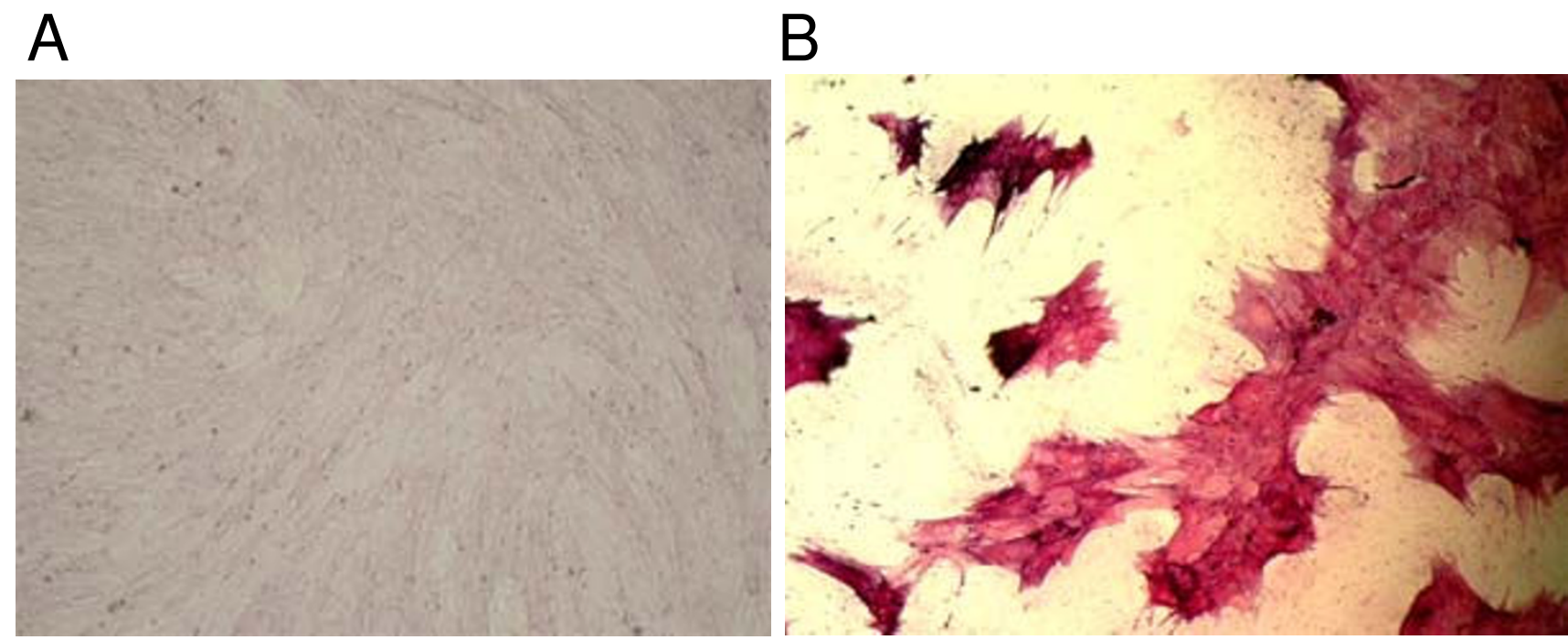

\section{C}

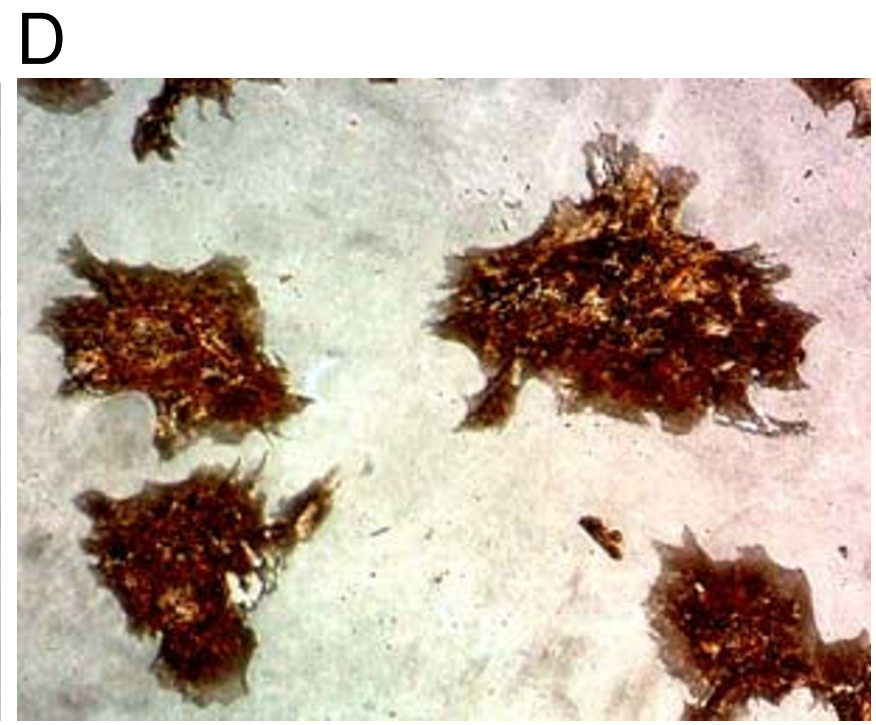

\section{Figure 6}

BM-MSCs osteogenic induction: alkaline phosphatase (AP) and von Kossa staining. After osteogenic induction cells showed a completely different morphology compared to untreated MSCs. (A, C): untreated control cells showing no staining for AP and von Kossa respectively (Magnification I0x). (B, D): AP and von Kossa positive staining in bone marrow-derived osteogenic cells. Magnification 20x.

cell marker antibodies, so far described in other species, show little or no cross-reactivity and thus cannot be used in the horse $[45,46]$.

In this paper we show that horse BM-MSCs can be induced to differentiate in tenocytes. Following exposure to BMP-12 the BM-MSCs expressed two tendon-related markers, tenomodulin and decorin [31-33]. To rule out the possibility that BMP-12 had induced differentiation into other cell types, rather than tenocytes, P19 lipocalin expression was assayed. In the BM-MSCs no expression of this gene, which is known to be expressed in reproductive system tissues like endometrium and uterus [34] was assessed. The BM-MSCs also maintained their capability to differentiate into osteoblast lineage, which was confirmed by two different staining techniques to detect the presence of calcium deposits and positivity for alkaline phosphatase. In literature many reports have shown that MSCs have multilineage differentiation capabilities [710]. However, up to now there has been no report of tenocytes induction. Although the possibility of using transplanted mesenchymal stem cells for tissue repair has been suggested in rabbits [50], little it is known about capability of mesenchymal stem cells to differentiate into tissue- 
specific cell types in vivo. However, a combination of mechanical stimuli and proximity to tenocytes and tendon matrix are believed to be important as stimuli for differentiation into tendon cells, as shown by direct implantation of cells into the tendon. The transplantation of mesenchymal stem cells into injured tendons has been shown to promote tendon healing not only in laboratory animal models [50] but also in horses [51,52].

PLGA (poly(lactic-co-glycolic acid) fibres have been used as scaffolds in therapeutic approaches to tendon repair, owing to their biodegradability and biocompatibility [53]. However, 3D scaffolds have not shown any results in the case of tendon repair in horses. So far, many approaches have been investigated for improvements in tendon injury repair, but most are not completely understood and much further effort is necessary to develop the technology into a highly efficient treatment. The promise of functional tissue engineering to replace damaged organs or tissues has boosted research interest. At present, however, it is important to balance the understanding of our current limitations with a desire to progress the technology. The possibility to use MSCs that have been predifferentiated into tendon cells for transplantation may represent a significant improvement over the use of undifferentiated cells.

For instance, there are some evidences of tumor induction by undifferentiated cells; more investigations in this matter, though, are needed [54].

\section{Conclusion}

In summary, our study has confirmed, at molecular level through gene specific DNA markers and their expression patterns, that BM-MSCs possess the capability of differentiating into tenocytes. These data will be the basis of future efforts to standardize the isolation, expansion and transplantation of equine differentiated and undifferentiated stem cells in clinical practice.

\section{Methods \\ Isolation of BM cells}

Bone marrow (BM) samples were obtained aseptically from sternal aspirates of an 8-year-old Dutch Warmblood mare during surgery for hock arthroscopy under general anesthesia with the owner consensus at the Large Animal Hospital of the Faculty of Veterinary Medicine in Lodi. The harvest site was clean shaved, clipped and aseptically prepared.

The intersternebral spaces were easily identified by diagnostic ultrasonography and bone marrow needles (11 gauge, $10 \mathrm{~cm}$ ) were used to aspirate marrow in two $20 \mathrm{ml}$ syringes containing 30,000 units of sodium heparin each
(Teofarma, Pavia, Italy). Immediately after collection, samples were stored on ice.

Preparation of MSC was achieved as follows. BM $(30 \mathrm{ml})$ was layered over Hystopaque ${ }^{\mathrm{TM}} 1.077$ (Sigma Aldrich, St. Louis, MO) and centrifuged for $20 \mathrm{~min}$ at $400 \mathrm{~g}$ and $4{ }^{\circ} \mathrm{C}$. The MSC-enriched cell population above the Hystopaque $^{\mathrm{TM}}$ layer was aspirated and washed in calcium and magnesium-free Dulbecco's Phosphate Buffered Solution (PBS) by further centrifugation at $260 \mathrm{~g}$ for 5 minutes at $4{ }^{\circ} \mathrm{C}$. The cell pellets were resuspended in $10 \mathrm{ml}$ Dulbecco Modified Earle's Medium (DMEM) supplemented with $10 \%$ fetal calf serum (FCS), penicillin $(100 \mathrm{U} / \mathrm{ml})$ and streptomycin $(\mathrm{P} / \mathrm{S})(100 \mu \mathrm{g} / \mathrm{ml})$, non-essential amino acids (NEAA 1\%), and seeded in 24-well plates (TPP, Trasadingen, Switzerland). All reagents were purchased from Euroclone (Milan, Italy).

Cells were checked for adhesion 3-4 days after plating and the medium was replaced with fresh medium containing Epidermal Growth factor (EGF) $50 \mathrm{ng} / \mathrm{ml}$ as specific growth factor (R\&D System, Minneapolis, MN). After 2 weeks, when the cells were actively proliferating, they were sub-cultured every 3-4 days, counted and seeded in T25 flasks $\left(4 \times 10^{5}\right.$ cells/flask $)$ or 24 -well plates $\left(2 \times 10^{5}\right.$ cells $/ \mathrm{ml}$ ) and incubated at $37^{\circ} \mathrm{C}, 5 \% \mathrm{CO}_{2}$. Photographs under AE30 Motic phase-contrast microscope were taken at passage 3 .

\section{Proliferation study}

To determine BM-MSCs doubling time, cells were plated at a density of 7,5 $\times 10^{3}$ nucleated cells/well in a 6-well plate (Corning Inc, Corning, NY) and incubated in the growth medium described above. Cells were harvested daily sequentially from replicate cultures over seven consecutive days and cell number determined using a Burker chamber. Experiments were performed in triplicate. The mean number of cells was calculated and plotted on a common log scale against culture time to generate a growth curve. The mean doubling time was obtained by the formula [55]: $\mathrm{PD}=\left(\operatorname{lgNt}-\lg \mathrm{N}_{0}\right) / \lg 2$ where $\mathrm{N}_{0}$ is the initial cell number; $\mathrm{Nt}$ is the cell harvest number at time $\mathrm{t}$. Doubling times between day 1 and day 7 in culture were calculated.

\section{Immunocytochemistry}

Cultured BM-derived stem cells were formalin fixed for 10 min, washed in PBS and permeabilized with $0.1 \%(\mathrm{v} / \mathrm{v})$ Triton X-100 in PBS for 20 min. Cells were incubated with 1:50 specific goat polyclonal antibody raised against Oct4 (Santa Cruz Biotechnology, Germany) for $2 \mathrm{~h}$ at $37^{\circ} \mathrm{C}$, followed by incubation for $2 \mathrm{~h}$ at room temperature with secondary biotin-conjugated donkey anti-goat IgG antibody (1:200) (Santa Cruz Biotechnology, Germany). Negative controls were incubated only with secondary 
antibody under the above condition. Excess secondary antibody was removed by repeated washing with PBS. Avidin, biotinylated horseradish peroxydase and 3,3'Diaminobenzidine (DAB) were applied according to the manufacturer's instructions using Vectastain ABC kit (DBA Italia s.r.l., Italy). Images were obtained with a phase contrast microscope under a $20 \times$ magnification.

\section{"Stemness" Marker Analysis}

$R T-P C R$ reaction and conditions

Total RNA was isolated from BM-MSCs at $5^{\text {th }}$ passage using the RNeasy kit (Qiagen, Milan, Italy). Total RNA was dissolved in $30 \mu \mathrm{l}$ of RNase-free water and was kept at $-80^{\circ} \mathrm{C}$ until analysis. The RNA concentration was determined using a NanoDrop ND-1000 spectrophotometer (NanoDrop, Wilmington, DE). Total RNA (0.5 $\mu \mathrm{g})$ was converted to cDNA with RevertAid H Minus M-MLV RT reverse transcriptase (Fermentas Int. Inc, Ontario). The obtained cDNA was amplified in $1 \times$ PCR buffer, with 0.5 $\mu \mathrm{M}$ sense and antisense primers, and $5 \mathrm{U}$ Taq Gold polymerase (Applied Biosystem, Foster City, CA) using an Eppendorf Mastercycler Gradient (Eppendorf AG, Germany).

Gene-specific amplicons for the Nanog, Oct4, Sox2 and CD34 genes were obtained using primer pairs designed based on equine gene specific sequences where available, otherwise primers were designed using gene specific sequences from other species that are present in public databases (Table 1; primer sequences for the characterization protocol of equine stem cells are covered by patent applications owned by Fondazione Parco Tecnologico Padano).

The conditions for PCR amplification were as follows: 10 minutes at $95^{\circ} \mathrm{C}$, followed by 35 cycles of 45 seconds at $95^{\circ} \mathrm{C}, 30$ seconds at $58^{\circ} \mathrm{C}, 30$ seconds at $72^{\circ} \mathrm{C}$, followed by a final extension step of 5 minutes at $72^{\circ} \mathrm{C}$. PCR products were resolved by electrophoresis on $2 \%$ agarose gels, visualized by ethidium bromide staining and photographed under ultraviolet light trans-illuminator (BioRad, Hercules, CA).

\section{Quantitative RT-PCR reaction and conditions}

BM-MSCs cDNA was used as the template for QRT-PCR of Nanog, Oct4 and Sox2 genes. Analysis of GAPDH gene was added as reference for housekeeping gene expression level.

All reactions were carried out in a total volume of $10 \mu \mathrm{l}$, containing $0.5 \mu \mathrm{M}$ of each primer, $5 \mu \mathrm{l}$ of Sybrgreen master mix 2× (Applied Biosystems) and 5-10 ng cDNA. Each PCR reaction was carried out in triplicate and amplifications were performed using an ABI Gene Amplification 7900 Sequence Detection System (Applied Biosystems, Foster City, CA). A single optimized thermal protocol of $95^{\circ} \mathrm{C}$ for 10 minutes, 40 cycles of $95^{\circ} \mathrm{C}$ for 30 seconds, $61^{\circ} \mathrm{C}$ for 1 minute and a final extension at $72^{\circ} \mathrm{C}$ for 5 minutes was used for all primer pairs. Dissociation curve analysis was run to ensure the absence of non-specific product.

Table I: Polymerase chain reaction (PCR) primer sequences

\begin{tabular}{ll}
\hline GAPDH & $\begin{array}{l}\text { F: CAACGAATTTGGCTACAGCA } \\
\text { R: CTGTGAGGGGGAGATTCA }\end{array}$ \\
\hline CD34 & $\begin{array}{l}\text { F: ATTACACGGAAAACGGTGGA } \\
\text { R: AATTCGGTATCAGCCACCAC }\end{array}$ \\
\hline Oct4 & $\begin{array}{l}\text { F: TCCCAGGACATCAAAGCTGCAGA } \\
\text { R: GTCAAACTTACGTACCCTCTCGGGTCT }\end{array}$ \\
\hline NANOG & F: TACCTCAGCCTCCAGCAGAT \\
& R: CATTGGTTTTCTGCCACCT \\
\hline TENOMODULIN & F: TGGTTACCTCTTCCTCCCACT \\
& R: GGGCAGTGTGCCGTTAAT \\
\hline DECORIN & F: GATCTTCACTTCCCTACCAACG \\
& R: CTCATCCAGCATGGGGTC \\
\hline LIPOCALIN & F: GAATGAGATCACCAAGCTGC \\
& R: TGAGATGCGAATGTATGAGAGA \\
\hline
\end{tabular}




\section{Data Analysis}

The $\Delta \Delta \mathrm{C}_{\mathrm{T}}$ method [56] was used to evaluate the relative expression levels among Nanog, Oct4 and Sox2 genes, using GAPDH as housekeeping gene.

\section{In Vitro Differentiation of BM-MSCs into tenocytes}

At the $5^{\text {th }}$ passage when BM-MSCs were $70 \%$ confluent, cells were trypsinized, counted and plated at a density of $6 \times 10^{5}$ onto a T25 culture flask. To induce tenocyte differentiation, cell cultures were maintained for 14-21 days in growth medium supplemented with BMP-12 $50 \mathrm{ng} / \mathrm{ml}$ (Tebu-Bio, Milan, Italy). The medium was changed every other day.

\section{Osteogenic differentiation}

BM-MSCs were plated at density of $1 \times 10^{4}$ cells/well and cultured in a 6-well-plate. Induction medium consisted of DMEM-HG, 10\% FCS, $1 \times \mathrm{P} / \mathrm{S}, 0.1 \mu \mathrm{mol} / \mathrm{l}$ dexamethasone, $0.025 \mathrm{mmol} / \mathrm{l}$ ascorbic acid-2-phosphate and $10 \mathrm{mmol} / \mathrm{l}$ $\beta$-glycerophosphate. All reagents were purchased from Sigma. Cells maintained in regular growth medium were used as negative control. After 2 weeks of induction, the cells were stained using the von Kossa procedure [57] to detect the presence of calcium deposition in osteocyte precursors. The positive and negative controls were also stained for alkaline phosphatase (Chemicon, Temecula, CA) according to the procedures described by the manufacturer. All the experiments were performed in triplicate.

\section{Authors' contributions}

SV conceived of the study, carried out most of the experiments and drafted the manuscript. PR carried out some molecular studies. LFP participated in data collection. CG carried out some molecular studies and helped to draft the manuscript. PM conceived of the study, coordination and helped to draft manuscript. All the authors read and approved the final manuscript.

\section{Acknowledgements}

We are grateful to Dr. John L. Williams and Prof. F. Cremonesi for the valuable discussion. We thank Dr. A. Lange Consiglio for the technical assistance.

\section{References}

I. Stevens M: Stem cells in regenerative medicine. The Pharmaceutical Journal 2005, 275:695-698.

2. Mimeault M, Batra SK: Concise review: recent advances on the significance of stem cells in tissue regeneration and cancer therapies. STEM CELLS 2006, 24:2319-2345.

3. Kemp KC, Hows J, Donaldson C: Bone marrow-derived mesenchymal stem cells. Leuk Lymphoma 2005, 46:I53I-I544.

4. Helder MN, Knippenberg M, Klein-Nulend J, Wuisman PI: Stem Cells from Adipose Tissue Allow Challenging New Concepts for Regenerative Medicine. Tissue Eng 2007, 13:1799-1808.

5. Weiss ML, Troyer DL: Stem cells in the umbilical cord. Stem Cell Rev 2006, 2:155- I62.

6. Ilancheran S, Michalska A, Peh G, Wallace EM, Pera M, Manuelpillai U: Stem Cells Derived from Human Fetal Membranes Display Multi-Lineage Differentiation Potential. Biol Reprod 2007, 7:577-88.
7. Herzog EL, Chai L, Krause DS: Plasticity of marrow-derived stem cells. Blood 2003, 102:3483-3492.

8. Holtorf HL, Jansen JA, Mikos AG: Flow perfusion culture induces the osteoblastic differentiation of marrow stroma cell-scaffold constructs in the absence of dexamethasone. J Biomed Mater Res A 2005, 72:326-334.

9. Bernardo ME, Emons JA, Karperien M, Nauta AJ, Willemze R, Roelofs H, Romeo S, marchini A, Rappold GA, Vukevic S, Localetlli F, Fibbe WE: Human mesenchymal stem cells derived from bone marrow display a better chondrogenic differentiation compared with other sources. Connect Tissue Res 2007, 48: I 32-I 40.

10. Yoon YS, Lee N, Scadova H: Myocardial regeneration with bone-marrow-derived stem cells. Biol Cell 2005, 97:253-263.

II. Potapova IA, Gaudette GR, Brink PR, Robinson RB, Rosen MR, Cohen IS, Doronin SV: Mesenchymal stem cells support migration, extracellular matrix invasion, proliferation and survival of endothelial cells in vitro. STEM CELLS 2007, 25: 176|-1768.

12. Bianco P, Riminucci M, Gronthos S, Robey PG: Bone marrow stromal stem cells: nature, biology, and potential applications. STEM CELLS 200I, 19:180-192.

13. Bernard-Beaubois K, Hecquet C, Houcine O, Hayem G, Adolphe M: Culture and characterization of juvenile rabbit tenocytes. Cell Biol Toxicol 1997, 13:103-II3.

14. Kannus P: Structure of the tendon connective tissue. Scand J Med Sci Sports 2000, 10:3 I2-320.

15. Rees SG, Flannery CR, Little CB, Hughes CE, Caterson B, Dent CM: Catabolism of aggrecan, decorin and biglycan in tendon. Biochem J 2000, I:I81-188.

16. Goh JC, Ouyang HW, Teoh SH, Chan CK, Lee EH: Tissue-engineering approach to the repair and regeneration of tendons and ligaments. Tissue Eng 2003, 9(Suppl I):3 I-44.

17. Ahmed T, Lutton JD, Feldman E, Tani K, Asano S, Abraham NG: Gene transfer of alpha interferon into hematopoietic stem cells. Leuk Res 1998, 22: I 19-1 24.

18. Woo SL, Hildebrand K, Watanabe N, Fenwick GA, Papageorgiou CD, Wang JH: Tissue engineering of ligament and tendon healing. Clin Orthop Relat Res 1999:312-323.

19. Cao Y, Vacanti JP, Ma X, Paige KT, Upton J, Chowanski Z, Schloo B, Langer R, Vacanti CA: Generation of neo-tendon using synthetic polymers seeded with tenocytes. Transplant Proc 1994, 26:3390-3392.

20. Awad HA, Butler DL, Boivin GP, Smith FN, Malaviya P, Huibregtse B, Caplan Al: Autologous mesenchymal stem cell-mediated repair of tendon. Tissue Eng 1999, 5:267-277.

21. Koob TJ, Willis TA, Qiu YS, Hernandez DJ: Biocompatibility of NDGA-polymerized collagen fibers. II. Attachment, proliferation, and migration of tendon fibroblasts in vitro. J Biomed Mater Res 200I, 56:40-48.

22. Jozsa L, Kvist M, Kannus $P$, Vieno $T$, Järvinen $M$, Lehto $M$ : Structure and macromolecular composition of the myotendineal junction. Histochemical, immunohistochemical and electron microscopic study of the rat calf muscles. Acta Morphol Hung 1991, 39:287-297.

23. Schwarz R, Colarusso L, Doty P: Maintenance of differentiation in primary cultures of avian tendon cells. Exp Cell Res 1976, 102:63-71.

24. Friedman MS, Long MW, Hankenson KD: Osteogenic differentiation of human mesenchymal stem cells is regulated by bone morphogenetic protein-6. J Cell Biochem 2006, 98:538-554.

25. Wozney JM: Bone morphogenetic proteins. Prog Growth Factor Res 1989, I:267-280.

26. Yu Y, Bliss JP, Bruce WJ, Walsh WR: Bone morphogenetic proteins and Smad expression in ovine tendon-bone healing. Arthroscopy 2007, 23:205-2I0.

27. Wang QW, Chen ZL, Piao YJ: Mesenchymal stem cells differentiate into tenocytes by bone morphogenetic protein (BMP) 12 gene transfer. J Biosci Bioeng 2005, 100:4| 8-422.

28. Lou J, Tu Y, Burns M, Silva MJ, Manske P: BPM-I2 gene transfer augmentation of lacerated tendon repair. J Orthop Res 200I, 19:1 199-1202.

29. Mays RW, van't Hof W, Ting AE, Perry R, Deans R: Development of adult pluripotent stem cell therapies for ischemic injury and disease. Expert Opin Biol Ther 2007, 7:173-184.

30. Shi W, Wang H, Pan G, Geng Y, Guo Y, Pei D: Regulation of the pluripotency marker Rex-I by Nanog and Sox2. J Biol Chem 2006, 28 I :23319-23325. 
31. Shukunami C, Takimoto A, Oro M, Hitakyi Y: Scleraxis positively regulates the expression of tenomodulin, a differentiation marker of tenocytes. Dev Biol 2006, 298:234-247.

32. Docheva D, Hunziker EB, Fassler R, Fassler R, Brandau O: Tenomodulin is necessary for tenocyte proliferation and tendon maturation. Mol Cell Biol 2005, 2:699-705.

33. Franchi M, Trire A, Quaranta M, Orsini E, Ottani V: Collagen structure of tendon relates to function. Scientific World Journal 2007, 7:404-420.

34. Crossett B, Allen WR, Stewart F: A I 9 kDa protein secreted by the endometrium of the mare is a novel member of the lipocalin family. Biochem J 1996, 320:137-143.

35. Guest DJ, Smith MR, Allen WR: Monitoring the fate of autologous and allogeneic mesenchymal progenitor cells injected into the superficial digital flexor tendon of horses: preliminary study. Equine Vet J 2008, 40:178-I8I.

36. Smith RK, Korda M, Blunn GW, Goodship AE: Isolation and implantation of autologous equine mesenchymal stem cells from bone marrow into the superficial digital flexor tendon as a potential novel treatment. Equine Vet J 2003, 35:99-102.

37. Fortier LA, Nixon AJ, Williams J, Cable CS: Isolation and chondrocytic differentiation of equine bone marrow-derived mesenchymal stem cells. Am J Vet Res 1998, 59:1 I82-II87.

38. Vidal MA, Kilroy GE, Johnson JR, Lopez MJ, Moore RM, Gimble JM: Cell growth characteristics and differentiation frequency of adherent equine bone marrow-derived mesenchymal stromal cells: adipogenic and osteogenic capacity. Vet Surg 2006, 35:60I-610

39. Lee RH, Kim B, Choi I, Kim H, Choi HS, Suh K, Bae YC, Jung JS: Characterization and expression analysis of mesenchymal stem cells from human bone marrow and adipose tissue. Cell Physiol Biochem 2004, 1 4:3II-324.

40. Winter A, Breit S, Parsch D, Benz K, Steck E, Hauner H, Weber RM, Ewerbeck V, Richter W: Cartilage-like gene expression in differentiated human stem cell spheroids: a comparison of bone marrow-derived and adipose tissue-derived stromal cells. Arthritis Rheum 2003, 48:4I8-419.

4I. Kisiday JD, Kopesky PW, Evans CH, Grodzinsky AJ, Mcllwraith CW, Frisbie DD: valuation of adult equine bone marrow- and adipose-derived progenitor cell chondrogenesis in hydrogel cultures. J Orthop Res 2008, 26:E322-33I.

42. Sakaguchi Y, Sekiya I, Yagishita K, Muneta T: Comparison of human stem cells derived from various mesenchymal tissues: superiority of synovium as a cell source. Arthritis Rheum 2005, 52:252I-2529.

43. Richardson LE, Dudhia J, Clegg PD, Smith R: Stem cells in veterinary medicine-attempts at regenerating equine tendon after injury. Trends Biotechnol 2007, 25:409-4I6.

44. Reed SA, Johnson SE: Equine umbilical cord blood contains a population of stem cells that express Oct 4 and differentiate into mesodermal and endodermal cell types. J Cell Physiol 2008 21 5:329-336.

45. Kadiyala S, Young RG, Thiede MA, Bruder SP: Culture expanded canine mesenchymal stem cells possess osteochondrogenic potential in vivo and in vitro. Cell Transplant 1997, 6:125-134.

46. Izadpanah R, Joswig T, Tsien F, Dufour J, Kirijan JC, Bunnel BA: Characterization of multipotent mesenchymal stem cells from the bone marrow of rhesus macaques. Stem Cells Dev 2005 | 4:440-45].

47. Saito S, Sawai K, Minamihashi Am Ugai H, Yokoyama KK: Derivation, maintenance, and induction of the differentiation in vitro of equine embryonic stem cells. Methods Mol Biol 2006, 329:59-79.

48. Hoynowski SM, Fry MM, Gardner BM, Leming MT, Tucker JR, Black L, Sand T, Mitchell KE: Characterization and differentiation of equine umbilical cord-derived matrix cells. Biochemical and Biophysical Research Communications 2007, 362:347-353.

49. Anjos-Afonso F, Bonnet D: Nonhematopoietic/endothelial SSEA- $I^{+}$cells define the most primitive progenitors in the adult murine bone marrow mesenchymal compartment. Blood 2007, 109:1298-1306.

50. Chong AK, Ang AD, Goh JC, Hui JH, Lim AY, Lee EH, Lim BH: Bone marrow-derived mesenchymal stem cells influence early tendon-healing in a rabbit achilles tendon model. J Bone Joint Surg Am 2007, 89:74-8I.
51. Herthel DJ: Enhanced suspenspory ligament healing in 100 horses by stem cell and other bone marrow components. In Proceedings of the 47th AAEP Annual Convention: November 24-28, 2001 Volume 47. San Diego (CA). American Association of Equine Practitioners; 2001:319-32I.

52. Pacini S, Spinabella S, Trombi L, Fazzi R, Galimberti S, Dini F, Carlucci F, Petrini M: Suspension of Bone Marrow-Derived Undifferentiated Mesenchymal Stromal Cells for Repair of Superficial Digital Flexor Tendon in Race Horses. Tissue Eng 2007, I 3:2949-2955.

53. Ouyang HW, Goh JC, Mo XM, Teoh SH, Lee EH: The efficacy of bone marrow stromal cell-seeded knitted PLGA fiber scaffold for Achilles tendon repair. Ann N Y Acad Sci 2002, 96I:126-129.

54. Tasso R, Augello A, Carida' M, Postiglione F, Tibiletti MG, Bernascon B, Astigiano S, Fais F, Truini M, Cancedda R, Pennesi G: Development of sarcomas in mice implanted with mesenchymal stem cells seeded onto bioscaffolds. Carcinogenesis 2009 , 30:150-157.

55. Horisberger MA: A method for prolonged survival of primary cell lines. In Vitro Cell Dev Biol Anim 2006, 42: |43-I48.

56. Livak KJ, Schmittgen TD: Analysis of relative gene expression data using real-time quantitative PCR and the 2(-Delta Delta C(T)) Method. Methods 200I, 25:402-408.

57. Sheehan DC, Hrapchak BB: Theory and practice of histotechnology 2nd edition. St. Louis: Mosby; 1980.
Publish with Biomed Central and every scientist can read your work free of charge

"BioMed Central will be the most significant development for disseminating the results of biomedical research in our lifetime. "

Sir Paul Nurse, Cancer Research UK

Your research papers will be:

- available free of charge to the entire biomedical community

- peer reviewed and published immediately upon acceptance

- cited in PubMed and archived on PubMed Central

- yours - you keep the copyright
BiolMedcentral 